\title{
MORPHOMETRIC DIFFERENCES BETWEEN THE PHYLOGEOGRAPHIC LINEAGES OF THE COMMON HAMSTER CRICETUS CRICETUS IN POLAND
}

\author{
AgATA BANASZEK ${ }^{1}$, JOANNA ZIOMEK ${ }^{2}$ and KATARZYNA A. JADWISZCZAK ${ }^{1}$ \\ ${ }^{1}$ Institute of Biology, University of Białystok; Świerkowa 20B, 15-950 Białystok, \\ Poland; banaszek@uwb.edu.pl \\ ${ }^{2}$ Department of Systematic Zoology, Adam Mickiewicz University; Umultowska \\ 89,61-614 Poznań, Poland; jziomek@amu.edu.pl
}

\begin{abstract}
As the common hamster is endangered in the European part of its range, it is necessary to define the conservation units for successful management of natural populations. Here we describe the case of clear morphometric differentiation between phylogeographic lineages of the common hamster. The standard external measurements were taken from 209 common hamsters collected during the period 2005-2007 from the present species range in Poland. The studied populations belong to different phylogeographic lineages P3 (Polish Pannonia) and E1, and the hamsters of P3 lineage are smaller with longer feet and tails than the hamsters of E1 lineage. The phylogeographic lineages of the common hamster can be defined as evolutionary significant units (ESU) due to the significant genetic differentiation and as management units (MU) with the evidence for ecological differentiation.
\end{abstract}

Key words: evolutionary significant unit (ESU), management unit (MU), morphometry, phylogeography

\section{INTRODUCTION}

Cricetinae are continental steppe animals adapted to open landscapes with the core area of occurrence situated in the Asian and Eastern European belt of steppes (WILSON and REEDER, 2005). The common hamster (Cricetus cricetus L.) is the only species of Cricetinae which extended its range from the Yenisei River in Asia as far as to Central and Western Europe, where the populations form 
some isolates (Niethammer, 1982). The species adapted to the conditions of arable lands and the existence of its populations in Europe was supported by the expansion of agriculture. The hamster was able to attain very high population densities described as mass outbreaks under favorable agriculture management. As a result, the species was considered to be a serious pest and fought vigorously with rodenticides and by hamster trappers (NeCHAY, 2000). However, since the 1970s, a decline in its numbers and fragmentation of the range could be observed. The intensity of the process varied from decreasing population density in some parts of the range to extinction, for example in the Netherlands (WEINHOLD, 2008). Recognizing the grave situation, the species was included in Appendix IV of the Habitats Directive, which provided strict protection in all EU countries.

The very drastic and rapid breakdown of the common hamster populations was observed among others in Poland (Ziomek and Banaszek, 2007). Just forty years ago the common hamster inhabited most of central and southern Poland. The species range did not include the northern parts of the country and high mountains in the south (SURDACKI, 1971). The area inhabited currently by the hamster is about one-fourth of the former species range and the species can be found in the Lublin Upland, Roztocze, the Małopolska Upland and some isolated populations in the surrounding areas (ZIOMEK and BANASZEK, 2007). Because of the dramatic shrinkage and fragmentation of the species range, it was proposed to change the species status from unknown (DD) (GŁowAciŃSKI, 2002) to endangered (EN) and to include it in the Polish Red Data Book of Animals ( Zіомек and BANASZEK, 2009). To maintain the species and avoid further deterioration, it is necessary to create the working program of the species protection. The first step is to establish conservation units, i.e. reach the decision if any populations within the species are sufficiently differentiated to require separate management.

In Europe protection measures were initially guided by the assumption that just two units existed formed by two subspecies: western European Cricetus cricetus canescens (Nehring, 1899) and central European C. c. cricetus (Linnaeus, 1758). However, the common hamster is a species with very little geographic variability and the existence of any subspecies has been doubted and criticized on the basis of the morphometric analyses (GRULICH, 1987). Moreover, as in most species that had been subjected to the phylogeographical analysis, it became apparent that the traditional subspecies did not correlate with the existence of the phylogeographic lineages. The nature of the genetic differences between C. c. canescens in western Europe and C. c. cricetus in eastern Germany is purely quantitative. C. c. canescens has lower genetic diversity, as a result of postglacial founder effects and current loss of genetic diversity caused by population decline (NeumanN et al., 2004).

So far three phylogeographic groups have been described in the European common hamster. The North group inhabits Germany and the west European countries at the edge of the species distribution range, hence the North lineage comprises populations of the former C. c. canescens and C. c. cricetus (NeUmanN 
et al., 2005). The Pannonian lineage inhabits the Carpathian Basin and it has been recently found, that it crossed the Carpathians into southern Poland. The E1 lineage was found to inhabit south-eastern Poland (BANAszeK et al., 2010a). The distribution range of this group must be larger and most probably extends into Ukraine, however no research was done in that area so far. The intraspecific divisions are clearly completely different from the earlier proposed division into subspecies.

The common hamster from Poland was classified as C. c. cricetus, while the phylogeographic analysis revealed the presence of two lineages: Pannonia (P3 in Poland) and E1 (BANAszeK et al., 2010a). Significant genetic differences between the two lineages might justify their management as separate units. However, to define management units (MU, Crandall et al., 2000), some ecological differentiation should also be demonstrated. The aim of this study was to compare the external measurements between the common hamster populations of E1 and P3 lineages in Poland.

\section{MATERIAL AND METHODS}

Two hundred and nine individuals of the hamster were collected during 2005-2007 from the present range of the species in Poland. The animals are most easily found after harvest, so the trapping was carried out invariably on August and September. Twelve populations were sampled: six from the E1 lineage - the populations from the Lublin Upland, Roztocze and north-eastern part of the Małopolska Upland and six populations from the P3 lineage - from the southwestern part of the Małopolska Upland, Krakow-Częstochowa Upland, Upper Silesia and Sandomierz Basin. During one session of trapping, the same individuals were sometimes collected. However, as we collected samples for the genetic analyses at the same time, the animals were marked by a small ear cut and easily recognized.

The hamsters were anesthetized for a short time, the standard external measurements were taken and the animals were released when fully recovered. Care was taken to measure the individuals with the muscles fully relaxed. The measurements were the body length (from the tip of the nose to the anus), tail length (from the anus to the tip of tail excluding the hair), hind foot length (from the end of the heel to the end of the longest toe, the claw excluded) and ear length (from the notch at the lower opening of the ear conch to the tip of the ear) (Pucek, 1981). The measurements were taken to the nearest $0.1 \mathrm{~mm}$ with a large vernier caliper for the body length and an electronic caliper for the remaining measurements. All the individuals were weighted with Pesola scales. The measurements were taken by the first two authors. Both collectors worked in the populations of both phylogroups and the potential measuring bias was checked by ANCOVA with no difference found. The color variant was also noted. The animals were caught under permissions of the Minister of the Environment DOPog.-402-02-54/04/aj, Warsaw 31.05.2004 and the Local Ethics Committee on the Animal Research in Bialystok 2003/53, Bialystok 21.01.2004. 
The comparison of external measurements between the phylogeographic lineages was performed by the ANCOVA with the body mass as covariant and two factors: sex and phylogeographic lineage. No climatic variables were included in the analysis, as the current species range in Poland is small and generally located in similar mesoregions. The normality of distribution and homogeneity of variance were tested prior to the analysis. The homogeneity of samples within the phylogeographic groups was tested by permutation tests in Blossom W2008.04.02 (MRPP - Multiresponse permutation procedures which can be used as permutation equivalent of the analysis of variance), as the size of the samples varied considerably. In some cases we found significant differences, however they invariably concerned the smallest samples while larger samples never differed significantly.

\section{RESULTS}

For the comparisons between the lineages we used the ANCOVA analysis performed on the whole sample. All the external measurements significantly correlated with the body mass ( $\mathrm{p}<0.001)$. According to Grulich (1987) all the standard external measurements in adult common hamster show clear sexual dimorphism and the differences between males and females are highly significant. Hence, we used two-factor analysis of covariance with sex and phylogeographic group as factors. Statistically significant differences in relation to the sex of the animal were found in the tail, hind foot and ear length, but not in the body length (Table 1). In GruLich's opinion (1987), the lack of significant differ-

Table 1. ANCOVA results for the comparisons between sexes and phylogeographic groups of the common hamster in Poland. Mean body mass as covariante $=214.9 \mathrm{~g}$. Interactions between factors sex and phylogroup insignificant in each case. The numbers given (in brackets) for the body length are the same for each following comparison. Body mass is in $\mathrm{g}$, lengths in $\mathrm{mm}$.

\begin{tabular}{cccccc}
\hline Measurement & Phylogroup & Males & Females & \multicolumn{2}{c}{ ANCOVA $p$} \\
\cline { 5 - 6 } & & & & sex & phylogroup \\
\hline Body length & E1 & $193.6(55)$ & $186.5(43)$ & 0.91 & $\mathbf{0 . 0 3}$ \\
& P3 & $189.5(70)$ & $184.5(41)$ & & \\
\hline Tail length & E1 & 42.6 & 42.4 & $\mathbf{0 . 0 0 4}$ & $<\mathbf{0 . 0 0 0}$ \\
& P3 & 44.8 & 46.4 & & \\
\hline Hind foot & E1 & 33.9 & 32.1 & $<\mathbf{0 . 0 0 0}$ & $<\mathbf{0 . 0 0 0}$ \\
length & P3 & 35.0 & 33.7 & & \\
\hline Ear length & E1 & 24.3 & 24.9 & $\mathbf{0 . 0 2}$ & 0.14 \\
& P3 & 24.1 & 24.3 & & \\
\hline
\end{tabular}


ences in some studies is simply a result of small sample size. The samples collected by Grulich were large, regularly over 500 individuals for particular years and they were collected during the peak of gradation. It is not possible to catch such numbers of hamster at present. On the other hand, our analysis was performed on the whole sample of juvenile and adult animals pooled, and this could mask the sexual dimorphism of adults.

Significant differences between the individuals representing P3 and E1 lineages were found in the length of body, tail and hind foot. In general, the Pannonian (P3) hamsters are smaller but with longer feet and tails (Table 1).

No color variants were observed in the present material from Poland, all the animals were typical.

\section{DISCUSSION}

To recommend any management action for natural populations, it is necessary to define conservation units. Sometimes, it would be desirable to manage separately groups of populations if they are sufficiently different. On the other hand, any management programs are costly, hence defining unjustified conservation units should be avoided, especially that populations may benefit from increased gene flow. Two definitions, the evolutionary significant unit ESU (Moritz, 1995) and management unit MU (Crandall et al., 2000) have been commonly used to estimate the level of population differentiation within conservation dependent species.

The ESUs may be defined by the use of genetic markers. Separate ESUs are significantly differentiated by mtDNA markers and nuclear loci (MoRITZ, 1995). The phylogeographic lineages of the common hamster in Poland meet the requirements of ESU, as they show significant differences in their mtDNA sequences between the lineages and monophyly within them (BANASZEK et al., 2010a). Moreover, the allele frequencies in microsatellite loci show small, however statistically significant differentiation between lineages (BANASZEK et al., 2010b). However, the concept of ESU has been criticized on the grounds that it does not take into account the ecological differences (Crandall et al., 2000). CRANDAll et al. (2000) proposed to define management units (MU) using the ideas of genetic and ecological exchangeability. Ecological exchangeability can be rejected if the populations are differentiated in any of the following: life history traits, morphology, habitat, QTLs, loci under selection, and the differentiation is due to genetic drift or natural selection. Here, we present evidence that two phylogeographic lineages of the common hamster show clear morphometric differences (Table 1).

The significant morphological differences reflect the long time of the independent, glacial evolution of the common hamster populations. The split between Pannonian and E1 lineages predates the last glacial maximum and falls roughly into the Eemian interglacial (BANASZEK et al., 2010a). The differentiation happened most probably in the refugia located in the southern Russian and Ukrainian plains (NeUmanN et al., 2005). The migration routes of the phylogroups 
were completely different. The E1 lineage populations colonized Poland from the east, while the Pannonian ones took the southern route into the Carpathian Basin and then through the Moravian Gate and the Dukla Pass could enter Poland (BANASZEK et al., 2010a). The long time of the independent evolution could result in chance accumulation of genetic differences other than mtDNA sequences that were the basis of the phylogeographic description.

Cases of morphological differentiation between phylogeographic lineages were reported also for other species. For example, in the common shrew (Sorex araneus L.), clear morphometric differentiation was found between two Siberian chromosomal races that represented different lineages originating in different refugia. The morphological differentiation was maintained even in the hybrid zone between the races (Polyakov et al., 2002). It is probable that in time of high densities of populations, hybrid zones could have also existed between the common hamster lineages, however at present, with less abundant populations and reduced chances of successful dispersal, no hybrid zones were found (Neumann et al., 2005; BAnAszek et al., 2009; 2010a). Such areas could have existed for example in the Małopolska Upland, inhabited in its northern and southern parts by the common hamster of different lineages. Hence, the morphological differentiation in the common hamster lineages was most probably also preserved in the face of hybridization.

The animals from the present hamster populations generally seem to be smaller than those collected before the population crash (PUCEK, 1981) and this may indicate a worse condition of the present populations. The survival chances of the animals are most probably much lower now, and they do not reach maximal body size. In our sample only two males were very big, with body weight of 570 and $595 \mathrm{~g}$; discounting these animals the maximum value of the body mass was $490 \mathrm{~g}$. It is noteworthy that GóRECKI (1977) reported even bigger animals, with body weight of 700-800.

The typical hamster fur is black on the belly, red-brown, yellow-brown to grey-brown on the back, with symmetrically arranged yellowish-white spots on the cheeks, behind the ears, in front of the forelimbs and behind them. Ear edges, feet and tip of the nose are white. There are no precise data on the presence of color variants in Poland, however at least black forms were reported from Silesia (PuceK, 1981). From Germany, where the data collected throughout the life of hamster trappers could be analyzed, white, piebald, yellow and black hamsters were reported with low frequency of $0.08 \%$. However, the general decrease in the frequency of color variations was noted, with none in the last decades (KAYser and Stubbe, 2000). No color variants were observed in the present material from Poland. The lack of such variants may also be the evidence of the overall loss of genetic diversity in the common hamster populations. The reduced genetic diversity of the common hamster in Poland is evident in the mtDNA control region variation, with seven haplotypes only found in the present species range (BANASZEK et al., 2009). The decreasing variability is also apparent in the number of alleles in microsatellite loci (BANASZEK et al., 2010b). The urgent conservation actions are therefore necessary with separate management of the phylogeographic lineages. 


\section{Acknowledgements}

The authors wish to express their gratitude to E. Chwełatiuk, M. Świsłocka, P. Jadwiszczak, M. Gąska and D. Andersz, who helped with the field work. The work was financed by the Polish State Committee for Scientific Research under grant no. 2P04F 01527.

\section{MORFOMETRYCZNE ZRÓŻNICOWANIE POMIĘDZY LINIAMI FILOGEOGRAFICZNYMI CHOMIKA EUROPEJSKIEGO CRICETUS CRICETUS W POLSCE}

Chomik europejski jest gatunkiem zagrożonym w całej europejskiej części zasięgu, istnieje więc konieczność zdefiniowania jednostek ochrony w obrębie gatunku w celu skutecznego zarządzania naturalnymi populacjami. Opisujemy tutaj przypadek wyraźnej różnicy morfologicznej pomiędzy liniami filogeograficznymi chomika europejskiego. Standardowe pomiary zewnętrzne zostały wykonane na 209 chomikach odłowionych w latach 2005-2007 z obecnego zasięgu gatunku w Polsce. Badane populacje należą do różnych linii filogeograficznych: P3 (Pannonia w Polsce) i E1 i stwierdzono, że chomiki linii P3 są mniejsze $z$ dłuższymi stopami i ogonami niż chomiki linii E1. Linie filogeograficzne chomika europejskiego mogą być więc zdefiniowane jako jednostki o znaczeniu ewolucyjnym (ESU), w związku z istotnym zróżnicowaniem genetycznym, i jednostki zarządzania (MU), z wykazanym zróżnicowaniem ekologicznym.

\section{REFERENCES}

Banaszek, A., Jadwiszczak, K.A., Ratkiewicz, M., Ziomek, J., 2009: Low genetic diversity and significant structuring of the common hamster populations Cricetus cricetus in Poland revealed by the mtDNA control region sequence variation. Acta Theriol., 54(4): 289-295.

Banaszek, A., Jadwiszczak, K.A., Ratkiewicz, M., Ziomek, J., Neumann, K., 2010a: Population structure, colonization processes and barriers for dispersal in the common hamster Cricetus cricetus (L.) populations in Poland. J. Zool. Syst. Evol. Res., 48(2): 151-158.

Banaszek, A., Jadwiszczak, K.A., Zıomek, J., 2010b: Genetic variability and differentiation in the Polish common hamster (Cricetus cricetus L.): Genetic consequences of agricultural habitat fragmentation. Mammal. Biol. (2010), doi:10.1016/j.mambio.2010.10.014

Blossom Statistical Package W2008.04.02. 2008: Fort Collins Science Center.

Crandall, K.A., Bininda-Edmonds, O.R.P., Mace, G.M., Wayne, R.K., 2000: Considering evolutionary processes in conservation biology: an alternative to 'evolutionary significant units'. TREE, 15: 290-295.

GŁowacińsKi, Z. /ed/, 2002: Red list of Endangered and Threatened Animals in Poland. PAN, Kraków: 1-155. [in Polish]

GórecKi, A., 1977: Energy flow through the common hamster population. Acta Theriol., 22: 25-66.

Grulich, I., 1987: Contribution to the sexual dymorphism of the hamster (Cricetus cricetus, Rodentia, Mammalia). Folia Zool., 36(4): 291-306. 
Kayser, A., Stubbe, M., 2000: Colour variation in the common hamster Cricetus cricetus in the north-eastern foot-hills of the Harz Mountains. Acta Theriol., 45(3): 377-383.

Moritz, C., 1994: Defining 'evolutionarily significant units' for conservation. TREE, 9: 373-375.

Nechay, G., 2000: Status of hamsters: Cricetus cricetus, Cricetulus migratorius, Mesocricetus newtoni and other hamster species in Europe. Nature and Environment series 106, Council of Europe Publishing, Strasbourg: 1-73.

Neumann, K., Jansman, H., Kayser, A., Maak, S., Gattermann. R., 2004: Multiple bottlenecks in threatened western European populations of the common hamster Cricetus cricetus (L.). Cons. Genet., 5: 181-193.

Neumann, K., Michaux, J.R., Maak, S., Jansman, H., Kayser, A., Mundt, G., Gattermann, R., 2005: Genetic spatial structure of European common hamsters - a result of repeated range expansion and demographic bottlenecks. Mol. Ecol. 14: 14731483.

Niethammer, J., 1982: Cricetus cricetus (Linnaeus, 1758) - Hamster (Feldhamster). /In:/ Handbuch der Säugetiere Europas, Bd. 2/I, Rodentia II. (Eds J. Niethammer, F. KRAPP). Akademische Verlagsgesellschaft, Wiesbaden: 7-28.

Polyakov, A.V., Onichenko, S.S., Ilyashenko, V.B., Searle, J.B., Borodin, P.M., 2002: Morphometric difference between the Novosibirsk and Tomsk chromosome races of the common shrew (Sorex araneus) in a zone of parapatry. Acta Theriol., 47(4): 381-387.

Pucek, Z. /ed/, 1981: Keys to Vertebrates of Poland. Mammals. Polish Scientific Publishers, Warszawa: 1-367.

Surdacki, S., 1971: The distribution and ranges of the European hamster Cricetus cricetus (Linnaeus, 1758) in Poland. Ann. UMCS, Lublin, Sectio B, 26: 267-285. [In Polish with English summary]

Wilson, D.E., Reeder, D.M.,/eds/, 2005: Mammal species of the world. A taxonomic and geographic reference. The Johns Hopkins University Press, Baltimore.

Weinhold, U., 2008: Draft European action plan for the conservation of the common hamster (Cricetus cricetus L., 1758). Convention on the conservation of European wildlife and natural habitatas, $28^{\text {th }}$ Meeting of the Standing Committee, Strasbourg: 1-36.

Ziomek J., Banaszek, A., 2007: The common hamster, Cricetus cricetus in Poland: status and current range. Folia Zool., 56 (3): 235-242.

Ziomer J., Banaszer A., 2009: Should the common hamster be included in the Polish Red Data Book of Animals? Chrońmy Przyrodę Ojczystą, 65(5): 341-346. [In Polish with English summary] 